\title{
Penicillin-binding proteins in Streptococcus faecalis and S. faecium
}

\author{
H. Y. CHEN and J. D. WILLIAMS
}

Department of Medical Microbiology, The London Hospital Medical College, London E1 2AD

Summary. Penicillin-binding proteins (PBPs) of Streptococcus faecalis NCTC 775, $S$. faecium NCTC 7171 and an isolate of $S$. faecium (strain 37) highly resistant to $\beta$-lactam antibiotics were visualised by autoradiography. Five PBPs were detected in S. faecalis NCTC 775 and six in S. faecium NCTC 7171. Additional PBPs could not be found in the resistant isolate of $S$. faecium.

The PBP affinities of $\beta$ lactams were compared with MIC values. The affinities of PBPs 3 and 4 of $S$. faecalis NCTC 775 for penicillin G, ampicillin, cefathiamidine, cephaloridine and cephazolin were related to the sensitivity of the strain to these antibiotics as were the affinities of PBPs 4 and 5 in each $S$. faecium strain for the $\beta$ lactams. It is postulated that PBPs 3 and 4 of S. faecalis NCTC 775 and PBPs 4 and 5 of $S$. faecium are the relevant target enzymes of the test antibiotics. PBPs 4 and 5 of the highly $\beta$-lactam-resistant $S$. faecium strain 37 showed proportionally low affinities for the five $\beta$ lactams compared to that of the less resistant strain $S$. faecium NCTC 7171. Decreased affinities of PBPs 4 and 5 may account for the resistance in $S$. faecium strain 37 to $\beta$ lactams. The affinities for PBP 1, 2 and 5 in S. faecalis NCTC 775 and PBPs 1, 2, 3 and 6 in $S$. faecium were not related to the antibiotic sensitivities.

\section{Introduction}

Three basic enzymes that are involved in synthesis of the cell wall are known to be sensitive to the action of penicillin. These are transpeptidases, carboxypeptidases and endopeptidases (Blumberg and Strominger, 1974; Strominger et al., 1974). Penicillin-binding proteins (PBPs) can be detected and quantified by an autoradiographic method (Spratt and Pardee, 1975; Georgopapadakou and Liu, 1980a), but their precise functions in cell growth and $\beta$-lactam activity remain unclear.

The role of PBPs of Escherichia coli and some other gram-negative species in growth, morphogenesis and $\beta$-lactam activity has been described to some extent (Spratt and Pardee, 1975; Spratt, 1983). PBPs of gram-positive bacteria have been studied less often than those of gram-negative bacteria. Alteration of PBPs has been reported in methicillin-resistant strains of Staphylococcus aureus (Hayes et al., 1981; Wyke et al., 1982; Ubukata et al., 1985) and in penicillin-resistant Streptococcus pneumoniae (Hakenbeck et al., 1980; Zighelboim and Tomasz, 1980).

The common mechanisms of resistance of bacteria to $\beta$-lactam antibiotics are the production of $\beta$

Received 14 May 1986; revised version accepted 6 Jul. 1986. lactamases that destroy the $\beta$ lactams, the reduced penetration of $\beta$ lactams through the outer membrane of gram-negative species (Nikaido, 1981), and alteration of affinity of PBPs for $\beta$ lactams. Enterococci rarely produce $\beta$ lactamase (Matthew and Harris, 1976; Murray and Mederski-Samaroj, 1983); there is no outer-membrane barrier, and no evidence that the peptidoglycan layer is a significant barrier to $\beta$ lactams (Williamson et al., 1983). Therefore, changes in the affinity of PBPs could have an important role in the mechanism of resistance to $\beta$ lactams.

Five PBPs have been found in Streptococcus faecalis and six in S. faecium (Georgopapadakou and Liu, 1980b; Eliopoulos et al., 1982; Williamson et al., 1983). The PBP affinities for $\beta$ lactams have been examined and the results are conflicting. Eliopoulos et al. (1982) showed nearly identical penicillin binding in two hypersensitive mutants of $S$. faecium and their parent strains. Williamson $e t$ al. (1983) examined the PBP affinities of one isolate each of $S$. faecalis and $S$. faecium for ampicillin and cephalothin and found that the affinities of lowmol. wt PBPs correlated broadly with the MICs. Fontana et al. $(1983 ; 1985)$ found a low-affinity PBP in $S$. faecium mutants highly resistant to $\beta$ lactams and the resistance correlated with the quantity of the PBPs. In the present study, the 
affinities of PBPs of $S$. faecalis and $S$. faecium for two penicillins and three cephalosporins were compared with their susceptibilities to these $\beta$ lactams. One highly $\beta$-lactam-resistant isolate of $S$. faecium was examined in parallel with the relatively susceptible strain of $S$. faecium, NCTC 7171.

\section{Materials and methods}

\section{Bacterial strains}

S. faecalis NCTC 775, S. faecium NCTC 7171 and a highly $\beta$-lactam-resistant clinical isolate of $S$. faecium, strain 37, were used. MICs were determined in Antibiotic Medium 3 (Bacto-penassay broth, Difco) by the broth dilution method. The inoculum was $c .10^{6} \mathrm{cfu} / \mathrm{ml}$.

\section{Antibiotics and protein mol. wt standards}

Benzyl $\left[{ }^{14} \mathrm{C}\right]$ penicillin potassium (specific activity 54 $\mathrm{Ci} / \mathrm{mol}$; Amersham International plc, Buckinghamshire) was used for labelling PBPs. Penicillin G (Glaxo Laboratories Ltd, Middlesex), ampicillin (Beecham Research Laboratories, Middlesex), cefathiamidine (Shanghai Third Pharmaceutical Co., Shanghai, China), cephaloridine (Glaxo) and cephazolin (Eli Lilly and Co. Ltd, Basingstoke) were used in the competition binding experiments. The mol. wt marker mixture included Low Molecular Weight Protein Standards (BIO-RAD Laboratories, CA, USA) and $\beta$-galactosidase (Sigma Chemical Co., St Louis, MO, USA).

\section{Preparation of bacterial membranes}

Antibiotic Medium 3 broth $(10 \mathrm{~L})$ was seeded with $100 \mathrm{ml}$ of an overnight culture and incubated at $37^{\circ} \mathrm{C}$ with shaking. Organisms at the late $\log$ phase of growth were harvested by centrifugation at $4000 \mathrm{~g}$ for $15 \mathrm{~min}$ and suspended in $60 \mathrm{ml}$ of cold $0.05 \mathrm{M}$ phosphate buffer, $p \mathrm{H}$ $7 \cdot 0$, containing $0.01 \mathrm{M} \mathrm{MgCl}_{2}$. Thirty $\mathrm{ml}$ of the cell suspension was mixed with $25 \mathrm{~cm}^{3}$ of glass beads $(0 \cdot 10$ $0.11 \mathrm{~mm}$ diameter) and subjected to violent shaking for 5 min in a Braun disintegrator (B. Braun Melsungen Appratebau, Melsungen, W. Germany). Cooling was achieved by spraying the apparatus with liquid $\mathrm{CO}_{2}$. Disruption of cells was confirmed by examination of gram-stained smears and viable counts; unbroken cells and debris were removed by centrifugation at $4000 \mathrm{~g}$ for $15 \mathrm{~min}$ at $4^{\circ} \mathrm{C}$. The supernate was retained and the membrane particles were deposited by ultracentrifugation at $100000 \mathrm{~g}$ for $30 \mathrm{~min}$ at $4^{\circ} \mathrm{C}$. The pellet was homogenised in $5 \mathrm{ml}$ of $0.01 \mathrm{M}$ phosphate buffer, $p \mathrm{H} 7 \cdot 0$, and ultracentrifuged at $100000 \mathrm{~g}$ for $30 \mathrm{~min}$ at $4^{\circ} \mathrm{C}$. The final pellet was resuspended in $5 \mathrm{ml}$ of $0.01 \mathrm{M}$ phosphate

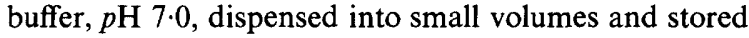
at $-70^{\circ} \mathrm{C}$ until used. Concentrations of protein in membrane preparations were estimated by the Lowry method with graded concentrations of bovine serum albumin (Sigma) as standards.

\section{Reaction of PBPs with ${ }^{14} C$-penicillin $G$}

(a) Direct PBP labelling. A mixture of $90 \mu 1$ of membrane preparation, $10 \mu \mathrm{l}$ of distilled water and $10 \mu \mathrm{l}$ of ${ }^{14} \mathrm{C}$-penicillin $\mathrm{G}$ (c. $350 \mathrm{mg} / \mathrm{L}$, specific activity $54 \mathrm{Ci}$ / mol) was prepared and incubated at $30^{\circ} \mathrm{C}$ for $10,20,40$ or $60 \mathrm{~min} ; 10 \mu \mathrm{l}$ of unlabelled penicillin $\mathrm{G}$ at a concentration of $60 \mathrm{~g} / \mathrm{L}$ was then added, followed $10 \mathrm{~min}$ later by $10 \mu \mathrm{l}$ of sodium lauryl sarkosinate $20 \%$, the mixtures being vortex mixed briefly after each addition. After 20 min at room temperature, the mixture was ultracentrifuged at $100000 \mathrm{~g}$ for $30 \mathrm{~min}$ at $10^{\circ} \mathrm{C}$. The supernate was mixed with 2-mercaptoethanol and sample buffer containing bromophenol blue $0.0075 \%$ sodium dodecyl sulphate (SDS) $3 \%$, and glycerol $30 \% \mathrm{v} / \mathrm{v}$ in $0.2 \mathrm{M}$ Tris$\mathrm{HCl}$ buffer $(p \mathrm{H} \mathrm{6.8)}$ in the proportion of 6:3:1 v:v:v. After heating at $100^{\circ} \mathrm{C}$ for $5 \mathrm{~min}$ the mixture was ready for electrophoresis.

(b) Competition binding experiments with other $\beta$ lactams. Serial two-fold dilutions of the test antibiotic were prepared at 10 times the final concentration required and $10 \mu \mathrm{l}$ of these dilutions were pipetted into Eppendorf centrifuge tubes. A control tube containing $10 \mu \mathrm{l}$ of water instead of the antibiotic solution was also prepared. To each tube was then added $90 \mu \mathrm{l}$ of the membrane preparation and after holding the mixture at $30^{\circ} \mathrm{C}$ for 10 min, $10 \mu \mathrm{l}$ of ${ }^{14} \mathrm{C}$-penicillin $\mathrm{G}(c .350 \mathrm{mg} / \mathrm{L}, 54 \mathrm{Ci} / \mathrm{mol})$ was added to each tube. After incubation at $30^{\circ} \mathrm{C}$ for a further $10 \mathrm{~min}, 10 \mu \mathrm{l}$ of unlabelled penicillin $\mathrm{G}(60 \mathrm{~g} / \mathrm{L})$ was added. The other procedures were the same as described as the direct labelling.

\section{Electrophoresis of soluble membrane proteins}

Sodium dodecyl sulphate polyacrylamide-gel electrophoresis (SDS-PAGE) was used for analysis of the sarkosyl-soluble membrane proteins (Boulton and Orr, 1983). A discontinuous slab gel system with a gel thickness of $1.5 \mathrm{~mm}$ was prepared in a 'Protean' slab gel apparatus (Bio-Rad Ltd, Herts). The separating gel contained 10\% acrylamide $10 \%, \mathrm{~N}, \mathrm{~N}^{\prime}$-methylene-bis-acrylamide $0.1 \%$, SDS $0.1 \%$, freshly prepared ammonium persulphate $0.05 \%$ and $\mathrm{N}, \mathrm{N}, \mathrm{N}^{\prime}, \mathrm{N}^{\prime}$-tetramethylethylenediamine (TEMED) $0.05 \% \mathrm{v} / \mathrm{v}$ in $0.375 \mathrm{M}$ Tris [(hydroxymethyl)methylamine]-HCl buffer $(p \mathrm{H} 8 \cdot 8)$. The stacking gel consisted of acrylamide $6 \%, \mathrm{~N}, \mathrm{~N}^{\prime}$-methylene-bisacrylamide $0.06 \%$, SDS $0.1 \%$, ammonium persulphate $0.05 \%$ and TEMED $0.1 \% \mathrm{v} / \mathrm{v}$ in $0.375 \mathrm{M}$ Tris $\mathrm{HCl}$ buffer, $p \mathrm{H} 6 \cdot 8$.

Appropriate volumes of the membrane-proteins preparations $(10 \mu \mathrm{l}$ for $S$. faecalis and $15 \mu \mathrm{l}$ for $S$. faecium) and standard protein markers were loaded into the wells of the gel. Electrophoresis was performed at a constant current of $20 \mathrm{~mA}$. The running buffer contained $0.05 \mathrm{M}$ Tris, $0.38 \mathrm{M}$ glycine and SDS $0.1 \%$. The gel was stained with Coomassie Brilliant Blue R (Boulton and Orr, 1983). The profiles of proteins separated in the gel were recorded by photography and compared. The relative mobilities of the standard proteins were measured. The gels were then prepared for fluorographic detection of the radiolabelled PBPs. 


\section{Fluorography}

The gels were prepared for fluorography as described by Boulton and Orr (1983). The X-ray plates were exposed to the gels for 100 days at $-70^{\circ} \mathrm{C}$. The PBPs were developed as dark bands and the amount of $\beta$ lactams required to inhibit $50 \%$ of binding of radiolabelled penicillin $\mathrm{G}$ was judged visually.

\section{Results}

\section{Electrophoresis of membrane proteins}

The protein concentrations of the membrane preparations were determined as $6-9 \mathrm{mg} / \mathrm{ml}$.

Staining of electrophoresed membrane proteins from enterococci with Coomassie Brilliant Blue $\mathbf{R}$ showed a range of protein species (fig. 1) and the protein profile of $S$. faecalis NCTC 775 was

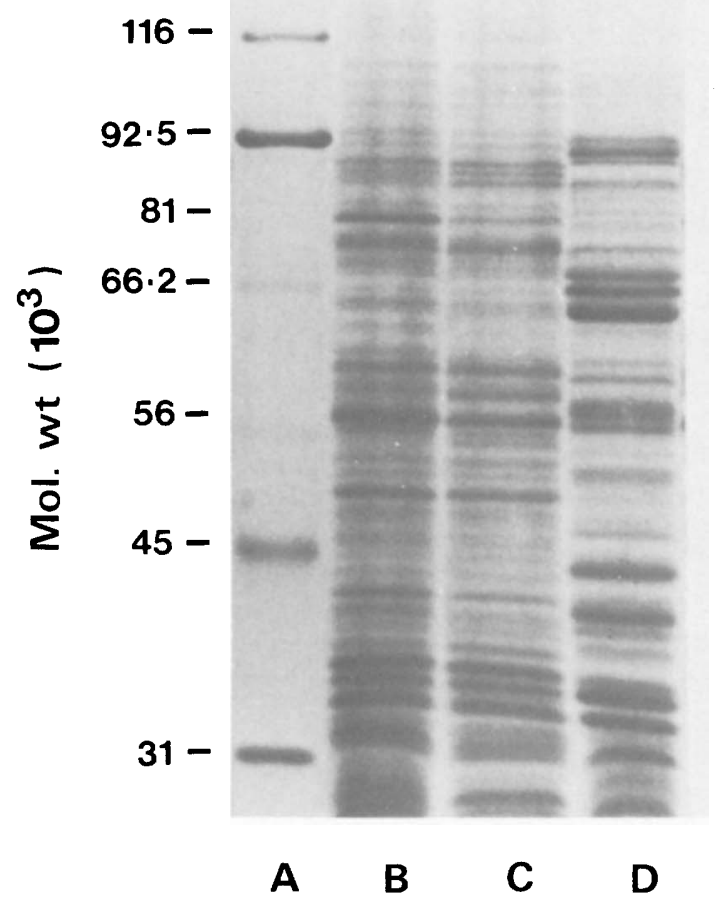

Fig. 1. Comparison of membrane protein profiles of enterococci. Tracks A: Protein mol. wt standards; B: S. faecium strain 37 ; C: $S$. faecium NCTC 7171 ; D: $S$. faecalis NCTC 775 . Two arrows indicate two proteins increased in amounts in resistant $S$. faecium strain 37 compared with $S$. faecium NCTC 7171 . substantially different from those of the $S$. faecium strains. The two $S$. faecium strains, resistant and moderately resistant to $\beta$ lactams, showed very similar protein profiles, but two more dense bands appeared in the resistant isolate of $S$. faecium strain 37 than in $S$. faecium NCTC 7171. The approximate mol. wts of the bands were 81000 and 56000 (fig. 1).

\section{Direct binding of PBPs to ${ }^{14} C$-penicillin $G$}

Five distinct PBPs were found in $S$. faecalis NCTC 775 whereas six PBPs were present in both $S$. faecium strains. The approximate mol. wts of PBPs $1-5$ of $S$. faecalis NCTC 775 were 100000 , $80000,78000,74000$ and 46000 , and those of PBPs 1-6 of $S$. faecium NCTC 7171 were 110000 , $86000,84000,80000,76000$ and 46000 ; those of S. faecium strain 37 were $110000,86000,83000$, 77000,74000 and 44000 .

Membrane proteins of the test strains were exposed directly to radioactive penicillin $G$ for different periods up to $60 \mathrm{~min}$ but no extra PBPs could be found in any of the test enterococci. Fig. 2 shows the PBPs of the resistant $S$. faecium strain 37 after different periods of exposure to ${ }^{14} \mathrm{C}$-penicillin G (fig. 2).

\section{Comparison of affinities of PBPs for $\beta$ lactams in relation to MICs}

MICs of S. faecalis NCTC 775 and S. faecium strains NCTC 7171 and 37 are shown in tables I and II in comparison with the PBP affinities for the antibiotics. $S$. faecalis NCTC 775 and $S$. faecium NCTC 7171 were relatively susceptible to some $\beta$ lactams whereas $S$. faecium strain 37 was resistant.

The affinity of a PBP for individual unlabelled $\beta$ lactams was expressed as the concentration of the antibiotic required to reduce ${ }^{14} \mathrm{C}$-penicillin $\mathrm{G}$ binding to the PBP by $50 \%$ (I50). The affinities of PBPs of $S$. faecalis NCTC 775, S. faecium NCTC

Table I. Inhibition of binding ${ }^{14} \mathrm{C}$-penicillin $\mathrm{G}$ to PBPs of $S$. faecalis NCTC 775 by five $\beta$ lactams

\begin{tabular}{|c|c|c|c|c|c|c|}
\hline \multirow{2}{*}{\multicolumn{2}{|c|}{$\begin{array}{l}\text { Antibiotic } \\
(\mathrm{MIC}, \mathrm{mg} / \mathrm{L})\end{array}$}} & \multicolumn{5}{|c|}{$\begin{array}{l}\text { Concentration }(\mathrm{mg} / \mathrm{L}) \text { required to in- } \\
\text { hibit by } 50 \% \text { binding to PBP }\end{array}$} \\
\hline & & 1 & 2 & 3 & 4 & 5 \\
\hline Penicillin G & (4) & 0.5 & 0.5 & 16 & 8 & $<0.25$ \\
\hline Ampicillin & (2) & 4 & 4 & 4 & 2 & $>128$ \\
\hline Cefathiamidine & (2) & 4 & 2 & 4 & 2 & $>128$ \\
\hline Cephaloridine & (32) & 2 & 128 & 16 & 64 & $<1$ \\
\hline Cephazolin & (64) & 128 & 64 & 512 & 64 & 512 \\
\hline
\end{tabular}




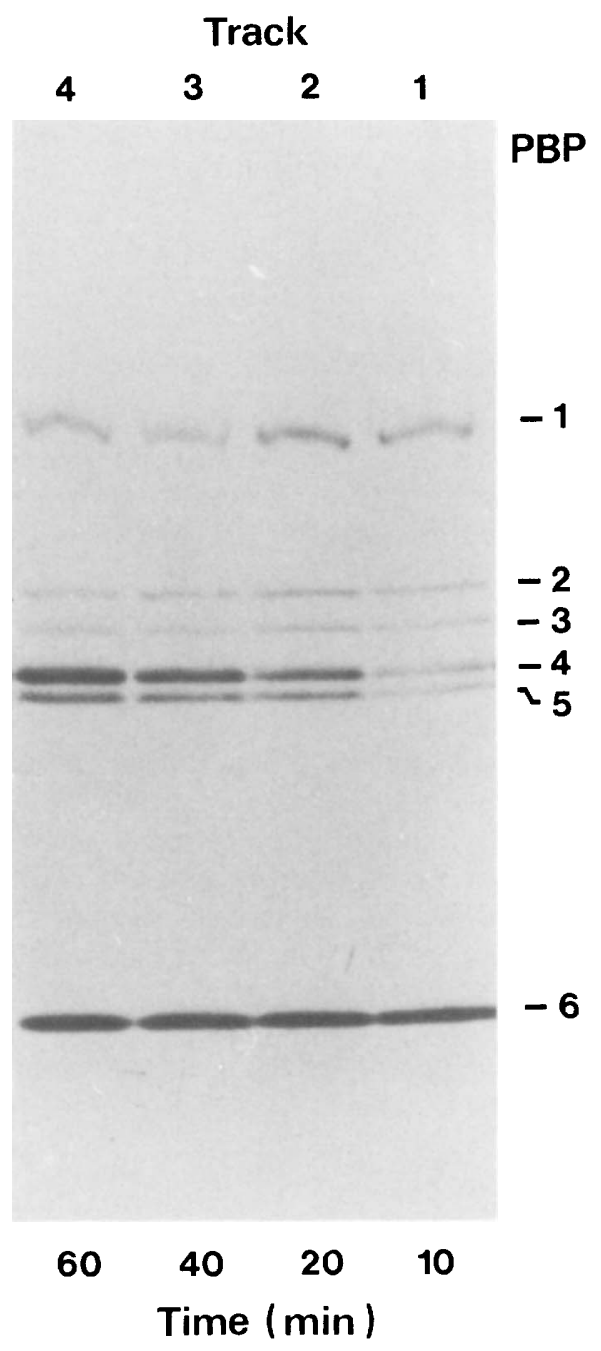

Fig. 2. Direct binding of radiolabelled penicillin $G$ to PBPs of $S$. faecium strain 37 . No extra PBPs were detected when the exposure time was increased from 10 to $60 \mathrm{~min}$ (tracks 1-4).

7171 and $S$. faecium strain 37 for five $\beta$ lactams are shown in tables I and II in comparison with MICs.

PBPs 1 and 2 of $S$. faecalis NCTC 775 (table I) showed 4-8-fold greater affinity for penicillin G than ampicillin and cefathiamidine, and PBP 5 had even greater affinity for penicillin $G$ compared to ampicillin and cefathiamidine, although ampicillin and cefathiamidine showed two-fold greater activity than penicillin G. PBPs 3 and 4 showed a more direct association between the affinity for the $\beta$ lactams and the antibacterial activity of these compounds.

The affinities of PBPs 4 and 5 of $S$. faecium for $\beta$ lactams were also proportionally related to respective MIC values. In the comparison of two strains of $S$. faecium, the affinities for PBPs 1, 2, 3 and 6 were similar, even though $S$. faecium strain 37 was far more resistant to the test $\beta$ lactams than was $S$. faecium NCTC 7171 (table II). PBPs 4 and 5 of the resistant $S$. faecium strain 37 showed lower affinities in comparison with those of $S$. faecium NCTC 7171. PBP 6 showed relatively high affinity for cephaloridine although cephaloridine was not active against $S$. faecium strain 37 . Figs. 3 and 4 show fluorographic results of the competition-binding experiments on $S$. faecalis NCTC 775, S. faecium NCTC 7171 and $S$. faecium strain 37.

\section{Discussion}

The ultrasonic treatment normally used for disruption of gram-negative bacteria appeared to be ineffective for enterococci. The reduction of viable counts after 5 min showed that the Braun disintegrator was as satisfactory with enterococci as with Staph. aureus (Huff et al., 1964).

There was a distinct difference in sarkosylsoluble protein components between $S$. faecalis and $S$. faecium strains (fig. 1). Our PBP profiles of $S$. faecalis and $S$. faecium (fig. 2) are similar to those of Georgopapadakou and Liu (1980b), Eliopoulos et al. (1982) and Williamson et al. (1983) Two $S$. faecium strains possessed six PBPs of nearly identical mol. wts despite the difference in their susceptibility to $\beta$ lactams. In a few experiments PBP 2 of $S$. faecium strains separated to form two close bands, almost identical in their binding characteristics; the reason for this phenomenon was obscure. It has been suggested that PBP patterns could be used for taxonomic purpose (Georgopapadakou and Liu, 1980a). Eliopoulos et al. (1982) selected two mutants that were highly susceptible to penicillin $\mathrm{G}$ from normally resistant isolates of $S$. faecium. Cell membranes prepared from resistant strains were found to possess a protein (mol. wt 82000 ) absent or less apparent in the membranes of susceptible strains. No alteration of PBP affinity was found in these mutants, therefore the protein was considered to be associated with the $\beta$-lactam resistance. In the present study, two proteins were found to be more dense in the resistant than in the susceptible $S$. faecium strain. One of the two protein bands had a mol. wt of 81000 (fig. 1) similar to the protein of mol. wt 82000 reported by Eliopoulos et al. (1982). This protein may be associated with $\beta$-lactam resistance or may be merely a phenomenon of strain variation. Detailed biochemical analysis is needed and it would be useful to see how widely it is distributed in $\beta$-lactam-resistant strains. 
Table II. Inhibition of binding of ${ }^{14} \mathrm{C}$-penicillin G to PBPs of resistant $S$. faecium strain 37 and of susceptible $S$. faecium NCTC 7171 by five $\beta$ lactams

\begin{tabular}{|c|c|c|c|c|c|c|c|c|c|c|c|c|c|c|}
\hline \multirow{3}{*}{$\begin{array}{l}\text { Antibiotic } \\
(\mathrm{MIC}, \mathrm{mg} / \mathrm{L})\end{array}$} & \multicolumn{14}{|c|}{ Concentration required to inhibit by $50 \%$ binding to $\mathrm{PBP}$} \\
\hline & \multicolumn{2}{|c|}{1} & \multicolumn{2}{|c|}{$2 a$} & \multicolumn{2}{|c|}{$2 b$} & \multicolumn{2}{|c|}{3} & \multicolumn{2}{|c|}{4} & \multicolumn{2}{|c|}{5} & \multicolumn{2}{|c|}{6} \\
\hline & 37 & $\mathbf{N}$ & 37 & $\mathrm{~N}$ & 37 & $\mathrm{~N}$ & 37 & $\mathbf{N}$ & 37 & $\mathbf{N}$ & 37 & $\mathbf{N}$ & 37 & $\mathbf{N}$ \\
\hline $\begin{array}{l}\text { Penicillin G } \\
(37: 125 ; \mathrm{N}: 4)\end{array}$ & $0 \cdot 25$ & $0 \cdot 25$ & $0 \cdot 063$ & 0.031 & 0.063 & 0.031 & $0 \cdot 125$ & $0 \cdot 125$ & 128 & 2 & 16 & 2 & 1 & 1 \\
\hline $\begin{array}{l}\text { Ampicillin } \\
(37: 63 ; N: 2)\end{array}$ & 1 & 0.5 & 0.031 & $0 \cdot 031$ & 0.031 & 0.031 & $0 \cdot 125$ & $0 \cdot 125$ & 64 & 0.5 & 8 & 0.5 & 2 & 4 \\
\hline $\begin{array}{l}\text { Cefathiamidine } \\
(37: 256 ; N: 8)\end{array}$ & $<1$ & $<0.5$ & $<1$ & $<0.5$ & $<1$ & $<0.5$ & $<1$ & $<0.5$ & 512 & 32 & 128 & 16 & 512 & 64 \\
\hline $\begin{array}{l}\text { Cephaloridine } \\
(37: 256 ; N: 8)\end{array}$ & $<1$ & $<0.25$ & & $<1$ & $<0.25$ & & $<1$ & $<0.25$ & 1024 & 32 & 512 & 16 & 4 & 4 \\
\hline $\begin{array}{l}\text { Cephazolin } \\
(37:>1024 ; N: 256)\end{array}$ & 4 & 4 & $\overparen{0.125}$ & $0 \cdot 125$ & 0.25 & 0.125 & 0.063 & 0.063 & 1024 & 512 & 1024 & 512 & 64 & 64 \\
\hline
\end{tabular}

$37=$ strain $37 ; \mathrm{N}=$ strain $\mathrm{NCTC} 7171$.

Fontana et al. $(1983 b ; 1985)$ showed that penicillin-resistant mutants of $S$. faecium strains carried a 'low-affinity' PBP which only became labelled after incubation for $20 \mathrm{~min}$ with radiolabelled penicillin G $48.5 \mathrm{mg} / \mathrm{L}$ and the amount of the PBP altered substantially with the extent of resistance. In this study, although the density of PBPs 4 and 5 of each
S. faecium strain in the direct binding experiments showed an increase with the reactive time from 10 to $60 \mathrm{~min}$ when the membrane was exposed to ${ }^{14} \mathrm{C}$ penicillin G $(54 \mathrm{Ci} / \mathrm{mol}): 35 \mathrm{mg} / \mathrm{L}$, no extra PBPs were observed with the increase in exposure time. Two distinct $S$. faecium strains were examined in this study, whereas resistant mutants or further

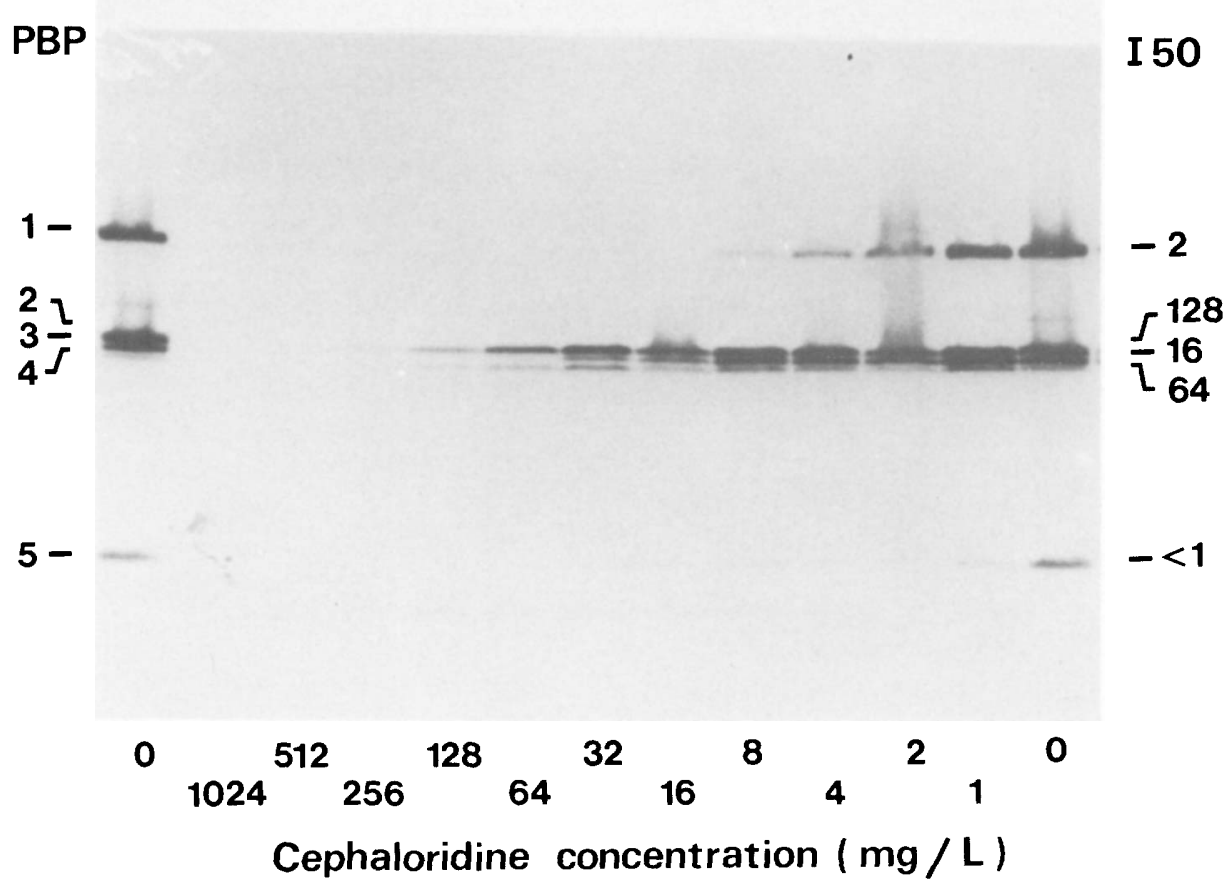

Fig. 3. Fluorogram of the competition binding experiment with $S$. faecalis NCTC 775 showing that the binding of radiolabelled penicillin $G$ to individual PBPs was inhibited by different concentrations of cephaloridine. 
A

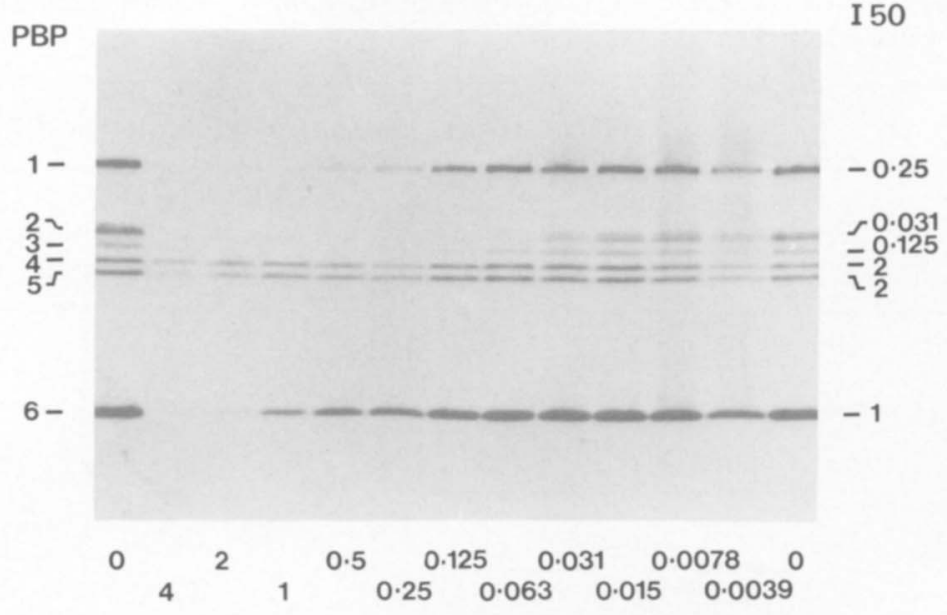

Concentration of unlabelled penicillin $G(\mathrm{mg} / \mathrm{L})$

B

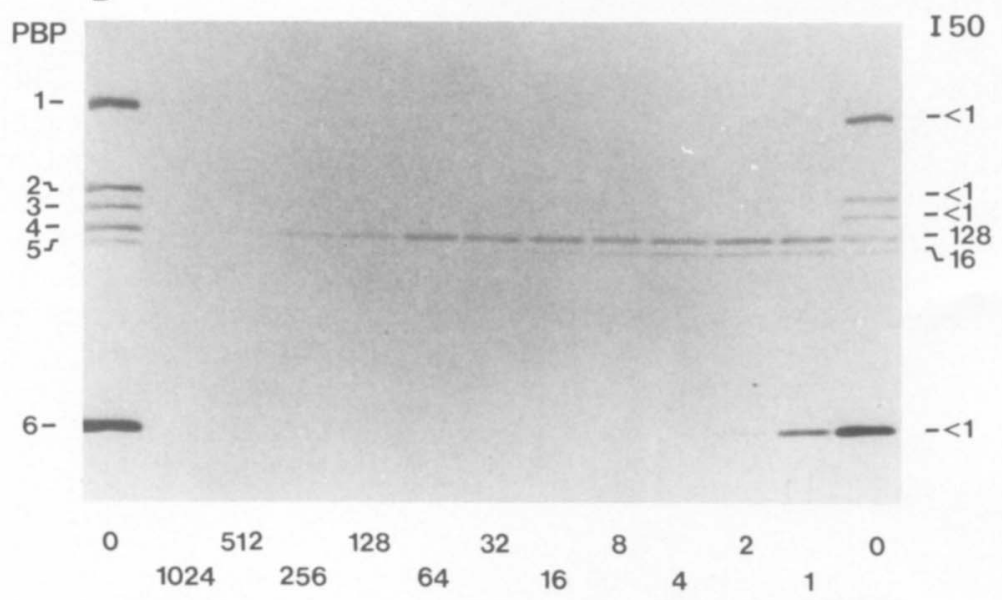

Concentration of unlabelled penicillin $\mathrm{G}(\mathrm{mg} / \mathrm{L})$

C

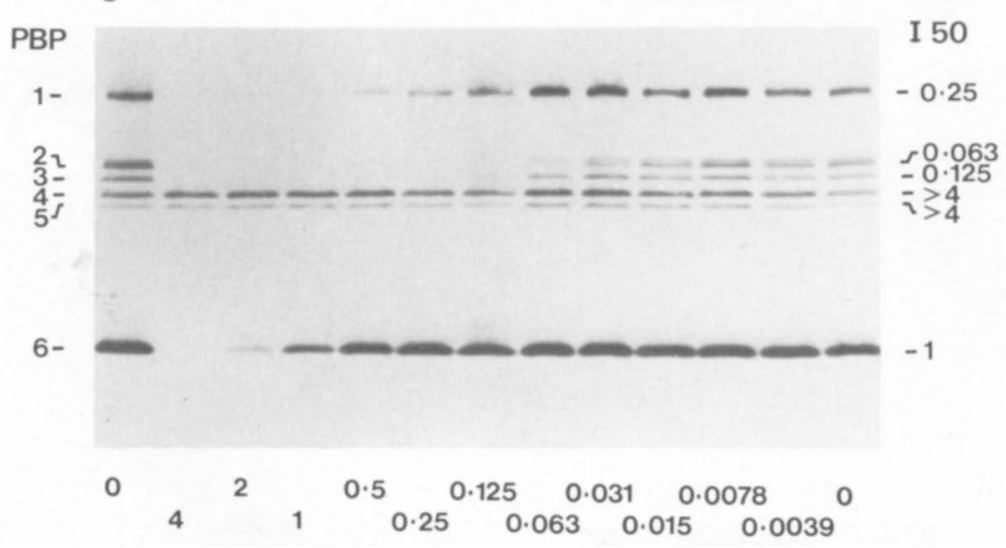

Concentration of unlabelled penicillin $G(\mathrm{mg} / \mathrm{L})$

Fig. 4. Comparison of fluorograms of competition experiments with unlabelled penicillin G on S. faecium NCTC 7171 (gel A) and S. faecium strain 37; gels B and C are two experiments including an extended range of unlabelled penicillin $\mathrm{G}$ concentrations. I50 values are listed on the right of the fluorograms. 
cured strains and their parental strains were used in the studies of Fontana et al. $(1983 b ; 1985)$. Strain difference might account for the discrepant results.

In the competition experiments we noted that individual PBPs showed different affinities for different $\beta$ lactams. In $S$. faecalis NCTC 775, high affinity of PBPs 3 and 4 for penicillin G, ampicillin and cefathiamidine (Chen and Williams, 1983) was associated with low MICs of the antibiotics; the relative affinities of PBPs 4 and 5 in the two $S$. faecium strains for the $\beta$ lactams were proportionate to their sensitivities to the antibiotics. It is presumed therefore that PBPs 3 and 4 of $S$. faecalis NCTC 775 and PBPs 4 and 5 of $S$. faecium are the relevant target sites of the test $\beta$-lactam antibiotics. Moreover, PBPs 4 and 5 of the highly $\beta$-lactam-resistant $S$. faecium strain 37 showed proportionally low affinities for the five $\beta$ lactams when compared with

\section{REFERENCES}

Blumberg P M, Strominger J L 1974 Interaction of penicillin with the bacterial cell: penicillin-binding proteins and penicillin-sensitive enzymes. Bacteriological Reviews 38: 291-335.

Boulton M G, Orr D C 1983 Detection of bacterial penicillinbinding proteins and their role in the interpretation of the role of action of beta-lactam antibiotics. In: Russell A D, Quesnal L B (eds) Antibiotics: assessment of antimicrobial activity and resistance. Academic Press, London, pp 161182.

Chen H Y, Williams J D 1983 The killing effects of cefathiamidine or ampicillin alone and in combination with gentamicin against enterococci. Journal of Antimicrobial Chemotherapy 12: 19-26.

Eliopoulos G M, Wennersten C, Moellering R C 1982 Resistance to beta-lactam antibiotics in Streptococcus faecium. Antimicrobial Agents and Chemotherapy 22: 295-301.

Fontana R, Cerini R, Longoni P, Grossato A, Canepari P 1983 Identification of a streptococcal penicillin-binding protein that reacts very slowly with penicillin. Journal of Bacteriology 155 : 1343-1350.

Fontana R, Grossato A, Rossi L, Cheng Y R, Satta G 1985 Transmission from resistance to hypersusceptibility to betalactam antibiotics associated with loss of a low-affinity penicillin-binding protein in a Streptococcus faecium mutant highly resistant to penicillin. Antimicrobial Agents and Chemotherapy 28: 678-683.

Georgopapadakou N H, Liu F Y $1980 a$ Penicillin-binding proteins in bacteria. Antimicrobial Agents and Chemotherapy 18: $148-157$.

Georgopapadakou N H, Liu F Y $1980 b$ Binding of beta-lactam antibiotics to penicillin-binding proteins of Staphylococcus aureus and Streptococcus faecalis: relation to antibacterial activity. Antimicrobial Agents and Chemotherapy 18: 834836.

Hakenbeck R, Tarpay M, Tomasz A 1980 Multiple changes of penicillin-binding proteins in penicillin-resistant clinical isolates of Streptococcus pneumoniae. Antimicrobial Agents and Chemotherapy 17: 364-371.

Hayes M V, Curtis N A C, Wyke A W, Ward J B 1981 Decreased affinity of a penicillin-binding protein for beta- those of relatively susceptible $S$. faecium NCTC 7171. Decreased affinities of PBPs 4 and 5 might account for the $\beta$-lactam resistance in $S$. faecium strain 37.

The affinities of PBPs 1,2 and 5 of $S$. faecalis NCTC 775 were not proportionally associated with MICs. The affinities of PBPs 1, 2, 3 and 6 of two $S$. faecium strains were very similar, whereas the difference in susceptibilities was remarkable for those two strains, e.g., PBP 5 of $S$. faecalis NCTC 775 had high affinity for cephaloridine but the strain was resistant to cephaloridine.

The experiments suggest that PBPs 1,2 and 5 of S. faecalis NCTC 775 and PBPs 1, 2, 3 and 6 of $S$. faecium are unlikely to be relevant to the action of the $\beta$ lactams. However, one $\beta$ lactam binds to multiple PBPs and it is likely that PBPs are functionally intercomplementary.

lactam antibiotics in a clinical isolate of Staphylococcus aureus resistant to methicillin. FEMS Microbiology Letters 10: 119-122.

Huff E, Oxley H, Silverman C S 1964 Density-gradient patterns of Staphylococcus aureus cells and cell walls during growth and mechanical disruption. Journal of Bacteriology 88: 1155-1162.

Matthew M, Harris A M 1976 Identification of beta-lactamases by analytical isoelectric focusing: correlation with bacterial taxonomy. Journal of General Microbiology 94 : 55-67.

Murray B E, Mederski-Samaroj B 1983 Transferable betalactamase. A new mechanism for in-vitro penicillin resistance in Streptococcus faecalis. Journal of Clinical Investigation 72: 1168-1171.

Nikaido H 1981 Outer membrane permeability of bacteria: resistance and accessibility of targets. In: Salton M R J, Shockman G D (eds) Beta-lactam antibiotics: mode of action, new developments and future prospects. Academic Press, New York, pp 249-260.

Spratt B G 1983 Penicillin-binding proteins and the future of beta-lactam antibiotics. Journal of General Microbiology 129: $1247-1260$.

Spratt B G, Pardee A B 1975 Penicillin-binding proteins and cell shape in E. coli. Nature 254 : 516-517.

Strominger J L, Willoughby E, Kamiryo T, Blumberg P M, Yocum R R 1974 Penicillin-sensitive enzymes and penicillin-binding components in bacterial cells. Annals of the New York Academy of Sciences 235: 210-224.

Ubukata K, Yamashita N, Konno M 1985 Occurrence of a betalactam-inducible penicillin-binding protein in methicillinresistant Staphylococci. Antimicrobial Agents and Chemotherapy 27: 851-857.

Williamson R, Calderwood S B, Moellering R C, Tomasz A 1983 Studies on the mechanism of intrinsic resistance to beta-lactam antibiotics in Group D streptococci. Journal of General Microbiology 129: 813-822.

Wyke A W, Ward J B, Hayes M V 1982 Synthesis of peptidoglycan in vivo in methicillin-resistant Staphylococcus aureus. European Journal of Biochemistry 127: 553-558.

Zighelboim S, Tomasz A 1980 Penicillin-binding proteins of multiply antibiotic-resistant South African strains of Streptococcus pneumoniae. Antimicrobial Agents and Chemotherapy 17: 434-442. 